https://ejournal.uniska-kediri.ac.id/index.php/PROFICIENCY

\title{
THE EFFECTIVENESS OF TEACHING WRITING BY USING PADLET AS THE MEDIA
}

\author{
By: \\ Betty Mahardica Ismawardani ${ }^{1}$ \\ Irwan Sulistyanto ${ }^{2}$
}

\begin{abstract}
Using Padlet as media is one of the ways to teach writing. Using Padlet as media help students make the students more excited in writing. The main purpose of the study is to examine the effectiveness of using Padlet as media on students' writing score of the tenth grade IIS-1. Quantitative was selected as a research approach, whereas the research design used was Quasi Experimental by using posttest-only design. This research used two classes which became experimental and control class. The experimental class was taught writing by using Padlet as media, while the control class was taught without any media. To collect the data, post writing tests in experimental and control group were administered. Data were analyzed by using t-test. The findings indicated that score of the experimental class higher than the control class. Thus, it can be concluded that using Padlet as media in teaching writing is effective.
\end{abstract}

Key word: padlet as media, teaching writing

\section{INTRODUCTION}

Writing is one of the English skills besides speaking, listening, and reading. Writing almost has the same characteristic as speaking, that is to communicate. What makes them different, in speaking, the purpose of communicating and showing the ideas is directly done by ignoring the grammatical mistakes in the spoken language. The purposse of writing is to communicate the ideas by looking at the grammatical mistakes, the readers can understand the message which will be extended by the writer effectivelyIn fact,

According to Harmer (2001:218), that the writing

\footnotetext{
${ }^{1}$ Graduate of English Department UNISKA Kediri

${ }^{2}$ Lecturer of English Department UNISKA Kediri
}

composition is a task which involves the students in manipulating words in grammatically correct sentences from a peace of continuous writing which successfully communicate the contents through any ideas on a certain topics. Writing refers to text. A composing some kinds of texts in written form for senior high school students' is one of the basic competence of English subject (Depdiknas:2006). It means that the students are demanded to be able to write some kinds of text with correct organization, appropriate vocabulary and grammar, and good mechanic of writing (punctuation, spelling and capitalization). There are thirteen 
genres or types of the texts thatshould be taught at senior high school, such as narrative, recount, procedure, report, analytical exposition, hortatory exposition, explanation, descriptive, discussion, news item, review, anecdote, and spoof. However, for the tenth grade students' of Senior High School, they only learn about narrative, procedure, recount and descriptive.

In learning writing skill, the students often find some problems. The problem frequently found is that their are daubt causes them difficult to use the foreign language. They are afraid if they are making a mistake in one of the text and lack of confident within themselves. Other reason is because lack of motivation to practice the second language daily. Moreover, the students' writing score is enough. Beside the reason above, usually the students feel bored with the media in teaching learning, students need a media that can attract their attention and provide comfort in learning writing. Arsyad (2002:1) states that media is something that used by someone or teacher to make easy on transferring the material or the subject to the students.

Teacher needs variations in teaching writing. The teacher has to find the media to make students' interested to build their self confidence in writing. According Lynne (2001) the students' interest is one of the main factors to achieve the goal of teaching learning English. For that reason, Padlet is a media that can be used to increase students' motivation in learning writing. There are three kinds of media in teaching learning process. They are audio, visual, audio visual.
According to Kurniawan and Lestari (2016:3) Padlet formerly Wall Wisher, is a web space where the admin can add files, links, videos, and more. By using this, tutor can create various walls to add your favorite content, giving a title, changing the background image. Tutor/teacher may develop the above wall to collect and share a few of his favorite technology resources. People can also collaborate to continue adding to the same wall space.

By using this, it can create a live discussion among the tutor and students. The aplication is similiar to Facebook, the student should make an account first in Padlet.com. The students can upload their answers and the other can read it without spending time. So, learning writing English by using Padlet is an innovative learning system to be developed although this is not a formal system but gives a nice effect in improving the English language.

Based on the explanation above, it can be seen that Padlet is one of media which is necessary to help the students understanding and learning writing to improve the writing score.

The study intends to answer the following questions; 1) How is the tenth graders' writing recount text ability in experimental group after taught by using media Padlet?; 2) How is the tenth graders' writing recount text ability in control group which does not taught by using media Padlet?; 3) Is there any significant difference of writing recount textability between the control and the experimental group?; and 4) Is media Padlet effective to be used in teaching 
https://ejournal.uniska-kediri.ac.id/index.php/PROFICIENCY

writing recount text ability at the tenth grade of MAN 4 Kediri?.

\section{RESEARCH METHOD}

The objective of this research was to investigate the effectiveness of teaching writing Recount text by using Padlet as the media at tenth grade of MAN 4 Kediri. Quantitative was selected as an approach to respond to research questions which require numerical data. Meanwhile, the research design selected was Quasi Experimental by using Posttest-Only Control-Group Design. This research used two classes; they were control class and experimental class.

Both classes were scored to determine the outcome. The scores were gotten from the test administered. The results of the test were used to find out whether the treatment applied in experimental class had an effect or a significant difference from control class or not. To find out the effectiveness of using Padlet as media to improve the students' writing score, the researcher computed data used the result of the test.

This research was done at MAN 4 Kediri, Badas, Kediri which is located at Jl. Melati No.14, Krecek, Badas, Kediri, East Java. The subjects was at the tenth grade. In determining the subject of research, it was randomly chosen that the subject or class chosen as the experimental class was X IIS - 1. The class consisted of 36 students. Meanwhile, the control class was X IIS - 2. The class consisted of 37 students.

Instrument has essential function to collect the data. It was the tool used to get the data related to the research focus. The research instrument in this research was test.

The test was is writing test. The students will be scored based on four components, they are content, organization, vocabulary, grammar and mechanics. If all components are good, they will get " 30 ". The lower score is "2" points. The test administered for control and experimental class was the same.

This sub-chapter discusses the procedures to get the data that used in conducting research. It presents; Test and Treatment.

a. Test

According to Arikunto (2006:151) test is series of question or practice and another device which is used to measure skill, intelligence, capability or talent which is belonged to individual or group. Post-test was given after they got teaching speaking by using Padlet as Media. The topic in post-test will about Past Experience, "My Best Experience".

\section{b. Treatment.}

This research typically involved two classes. Those classes were given different treatments. Experimental class (X IIS-1) was given a new treatment; that was have been taught by using Padlet as media. Meanwhile, control class (X IIS-2) was taught without any media.

The purpose of the test was to know the students' writing ability by giving some instruction. The steps for collecting data were: (1) Teacher will give a test. (2) Teacher will distribute the test to students. (3) Teacher will give instructions before students doing test. (4) Students do preparation for 5 minutes. (5) Students do the examination. (6) The teacher will give 
https://ejournal.uniska-kediri.ac.id/index.php/PROFICIENCY

the students' score. (7) The score of students' test was analyzed by using SPSS 22.0 version.

\section{RESEARCH FINDING The Students' Writing Score In Experimental Class}

The students in experimental Class were consist of 36 students. The students in experimental class were using Padlet for studying Recount text. On the first day thy studied Recount text, the second and third day they studied how to use Padlet, and the last day they did post-test as the final examination. The percentage of the students who get 'good' scores is $11.1 \%$, whereas $88.9 \%$ students get 'very good' scores. To sum up, the students' writing achievement in experimental class is in 'very good' category with the mean score 91.28. Furthermore, the mean score of experimental class is higher than the control class. From the explanation above, it can be concluded that Padlet can be used as media in teaching writing and increase the students' writing score.

\section{The Students' Writing Score In Control Class}

In the control class there were 37 students. In this class the students got different treatment than experimental. On the first day they studied Recount. On the second day the students analyze the structure of Recount text. The third devided become some groups, they arranged a random text to be a good paragraph. And the last day they did post-test. The percentage of the students who get 'fair' scores is $51.4 \%$, whereas $48.6 \%$ students get 'good' scores. To sum up, the students' writing score in control class is in 'fair' category with the mean score 68.86. From the explanation above, we know that the students' writing score in control class is lower than experimental class. Interpreting the result of Significant Difference between the Students' Writing score in Control and Experimental Class

After finding the results of both groups, the significant difference between students' writing score achievement in control and experimental class is calculated. SPSS version 22 is used to analyze the data.

Table of Statistic Difference between Control and Experimental Class Group Statistics

\begin{tabular}{|l|l|r|r|r|r|}
\hline & Class & \multicolumn{1}{|c|}{$\mathrm{N}$} & \multicolumn{1}{c|}{ Mean } & Std. Deviation & \multicolumn{1}{c|}{ Std. Error Mean } \\
\hline Score & Experimental & 36 & 91.28 & 3.844 & .641 \\
& Control & 37 & 68.86 & 6.889 & 1.132 \\
\hline
\end{tabular}

Group Statistics

The table reveals a difference in mean value between the control class $(\mathrm{M}=68.86, \mathrm{SD}=6.889)$ and the experimental class $(\mathrm{M}=91.28, \mathrm{SD}=$ 3.844). In order to examine whether the experimental class and the control class differed significantly in the test achievement, an independentsamples t-test was conducted using an alpha level of 0.05 . The result is indicated in table below: 
https://ejournal.uniska-kediri.ac.id/index.php/PROFICIENCY

Table of Independent Samples T-test Result

Independent Samples Test

\begin{tabular}{|c|c|c|c|c|c|c|c|c|c|}
\hline & \multicolumn{2}{|c|}{$\begin{array}{l}\text { Levene's } \\
\text { Test for } \\
\text { Equality of } \\
\text { Variances } \\
\end{array}$} & \multicolumn{7}{|c|}{ t-test for Equality of Means } \\
\hline & \multirow[t]{2}{*}{$\mathrm{F}$} & \multirow[t]{2}{*}{ Sig. } & \multirow[t]{2}{*}{$\mathrm{t}$} & \multirow[t]{2}{*}{ Df } & \multirow{2}{*}{$\begin{array}{l}\text { Sig. } \\
(2- \\
\text { tailed })\end{array}$} & \multirow{2}{*}{$\begin{array}{l}\text { Mean } \\
\text { Differ } \\
\text { ence }\end{array}$} & \multirow{2}{*}{$\begin{array}{l}\text { Std. } \\
\text { Error } \\
\text { Differe } \\
\text { nce }\end{array}$} & \multicolumn{2}{|c|}{$\begin{array}{l}95 \% \text { Confidence } \\
\text { Interval of the } \\
\text { Difference }\end{array}$} \\
\hline & & & & & & & & Lower & Upper \\
\hline \multirow{2}{*}{$\begin{array}{ll}\text { Sco } & \text { Equal variances } \\
\text { re } & \text { assumed } \\
& \begin{array}{l}\text { Equal variances } \\
\text { not assumed }\end{array}\end{array}$} & \multirow[t]{2}{*}{3.602} & \multirow[t]{2}{*}{.062} & 3.694 & 76 & .000 & 8.462 & 2.291 & 3.899 & 13.024 \\
\hline & & & & 69.409 & .000 & 8.462 & 2.291 & 3.892 & 13.031 \\
\hline
\end{tabular}

The interpretation of the table above is; there is significant difference between two groups if sig. (2-tailed) value is the same as or is lower than $5 \%$ or 0.05 . From table 4.8 , it can be seen that the experimental group outperformed the control group in writing score with $\mathrm{t}=$ 17.100, $d f=71$ and $\mathrm{P}=.000$ and $95 \%$ confidence interval ranging from 19.799 to 25.026 . From the sig. (2tailed) we can see the $\mathrm{P}$ is lower than $5 \%(0.000<0.05)$. So, it can be conclude that the t-value is significant in 5\% significant level. It means that there is significant difference between control and experimental class.

The Effectiveness of Using Padlet as media to Improve Students' Writing Score

After knowing t-test result, we can be concluded that Alternative Hypothesis $\left(\mathrm{H}_{\mathrm{a}}\right)$ is accepted. Alternative Hypothesis $\left(\mathrm{H}_{\mathrm{a}}\right)$ states: There is significant difference of students' writing recount text ability after taught using media Padlet at MAN 4 Kediri. Before testing this hypothesis, t-test is calculated to compare the means between the experimental and control groups. The result reveals that experimental group outperformed the control group with significance value $2 \%$ or 0.025 as indicated in table 4.8. It is supported with the previous study by Algraini, titled "The Effect of Using Padlet on Enhancing EFL Writing Performance". The result is using Padlet can improve students' writing ability. It means if it is effective. Significance value (sig. 2-tailed) 2\% or 0.025 is lower than alpha level of $5 \%$ or 0.05 . The significant different between both classes is found. Therefore, the Null Hypothesis is rejected in favor of the Alternative Hypothesis. Thus "There is no significant difference of students' writing recount text ability after taught using media Padlet at MAN 4 Kediri”.

\section{Conclusion}

After analyzing the data in chapter IV, the conclusions can be drawn are as follows;

1. The students' writing comprehension achievement in experimental class, which is taught by using Padlet as Media, is in a good category with the mean score 9128 .

2. The students' writing comprehension in control 
https://ejournal.uniska-kediri.ac.id/index.php/PROFICIENCY

class, which is not taught by Padlet as Media, is in a fair category with the mean score 68.86 .

3. There is significant difference between the experimental and control class' achievement. The result shows that experimental class' achievement is higher than control one. It is also proven by the result of independentsamples t-test which values of sig. 2-tailed is $0.000(\mathrm{P}, 0.05)$.

4. Padlet as Media is effective to be used in language teaching specifically in teaching writing. It is proven by the result of t-test $17.100>$ 0.516). so, the t-test is significant in 5\% significancy level.

\section{BIBLIOGRAPHY}

Algraini, F. N. A. 2014. The Effect of Using Padlet on Enhancing EFL Writing Performance. Thesis. College of Languages and Translation Department of English Language and Literature. Kingdom of Saudi Arabia: Al-Imam Muhammad Ibn Saud Islamic University

Arikunto, S. 2006. Prosedur Penelitian: Suatu Pendekatan Praktik. Jakarta: PT. Rineka Cipta.

Arsyad, Prof Azhar. 2002. Media Pembelajaran. Jakarta: Rajawali Press.

Depdiknas. 2006. Kurikulum Berbasis Kompetensi Mata Pelajaran Bahasa Inggris. Jakarta: Pusat Kurikulum Badab Penelitian dan Pengembangan Departemen Pendidikan.

Harmer, J. 2001. The Practice of English Language Teaching $3 r d$ Edition. Longman.

Kurniawan, E. H. \& Lestari, P. Y. 2016. Padlet as Media to
Improve Writing Mastery of English Department Students of Uniska 2015 -2016. ENGLISH FRANCA: Academic Journal of English Language and Education.

Lynne, C. 2001. Teaching Language to Young Learners. Cambridge University Press.

Taranto, G., Dalbon, M. \& Gaetano, j. 2011. Academic Social Networking Brings Web 2.0 Technologies to the Middle Grades. Middle School Journal, pp. 12-19. Retrieved http://cmsd.k12.pa.us/cmsd/c m_intsafe/documents/middles chooljournalarticlemay2011.p df (2 Agustus 2018).

Warnock, S. 2009. Teaching Writing Online: How \& Why. Urbana: National Council of Teachers of English. Retrieved from http://www.ncte.org/library/N CTEFiles/Resources/Books/S ample/52539Intro_X.pdf (2 Agustus 2018). 